\title{
MENINGKATKAN HASIL BELAJAR SISWA MELALUI PENDEKATAN KONTEKSTUAL DI KELAS V SDN 08 NAPABALANO
}

\author{
Dahlia $^{1)}$, Amiruddin B. ${ }^{2)}$ \\ ${ }^{1)}$ SDN 08 Napabalano, Muna, Indonesia \\ ${ }^{2)}$ Jurusan PGSD, Universitas Halu Oleo, Kendari, Indonesia \\ email: amiruddin.b@uho.ac.id
}

\begin{abstract}
Abstrak: Jenis penelitian ini adalah tindakan yang berdaurulang/siklus yang meliputi perencanaan, pelaksanaan, observasi, danrefleksi. Hasil penelitian inimenunjukkanbahwa Pendekatan Kontekstual dapat meningkatkan hasil belajar siswa materi Makhluk Hidup (Hewan danTumbuhan) Menyesuaikan Diri dengan Lingkungannya di kelas V SD Negeri 08 Napabalano. Hal ini dapat dilihat dari observasi aktivitas guru selama proses pembelajaran siklus I berlangsung diperoleh persentase aktivitas guru pada pertemuan I sebesar $60,00 \%$ dan pertemuan II sebesar 66,67\%. Aktivitas siswa selama proses pembelajaran Siklus I berlangsung diperoleh persentase aktivitas siswa pada pertemuan I sebesar $61,53 \%$ dan pertemuan II sebesar $69,23 \%$. Observasi aktivitas guru selama proses pembelajaran siklus II berlangsung diperoleh persentase aktivitas guru pada pertemuan I sebesar 93,33\% dan pertemuan II sebesar 93,33\%. Aktivitas siswa selama proses pembelajaran Siklus II berlangsung diperoleh persentase aktivitas siswa pada pertemuan I sebesar $92,30 \%$ dan pertemuan II sebesar 92,30\%. Nilai yang diperoleh siswa setelah tindakan pembelajaran siklus I dan siklus II dianalisis untuk mengetahui ketuntasan belajar siswa. Pada siklus I, 9 orang siswa $(60,00 \%)$ telah mencapai ketuntasan belajar,6 orang siswa $(40,00 \%)$ belum mencapai ketuntasan belajar. Sedangkan pada siklus II,15 orang siswa (100\%) telah mencapai ketuntasan belajar. Hal tersebut menunjukkan bahwa ketuntasan belajar siswa telah mencapai indikator yang telah ditetapkan
\end{abstract}

Kata kunci: Pendekatan Kontekstual; Hasil belajar siswa;

\section{IMPROVING STUDENT LEARNING OUTCOMES THROUGH A CONTEXTUAL APPROACH IN CLASS V SDN 08 NAPABALANO}

Abstract: This type of research is a cyclic action that includes planning, implementation, observation, and reflection. The results of this study indicate that the Contextual Approach can improve student learning outcomes on Living Things (Animals and Plants) Adjusting to their Environment in class V SD Negeri 08 Napabalano. This can be seen from the observation of teacher activity during the learning process in the first cycle, the percentage of teacher activity at the first meeting was $60.00 \%$ and the second meeting was $66.67 \%$. Student activity during the learning process in Cycle I took place, the percentage of student activity at the first meeting was $61.53 \%$ and the second meeting was $69.23 \%$. Observation of teacher activities during the learning process in cycle II took place, the percentage of teacher activity at the first meeting was $93.33 \%$ and the second meeting was 93.33\%. Student activity during the learning process in Cycle II, the percentage of student activity at the first meeting was $92.30 \%$ and the second meeting was $92.30 \%$. The value obtained by students after the learning action cycle I and cycle II were analyzed to determine student learning completeness. In the first cycle, 9 students (60.00\%) had achieved mastery learning, 6 students (40.00\%) had not yet achieved mastery learning. Whereas in cycle II, 15 students (100\%) had achieved mastery learning. This shows that students' learning completeness has reached the predetermined indicators

Keywords: Contextual Approach; Student learning outcomes 


\section{Pendahuluan}

Dalam Kurikulum Tingkat Satuan Pendidikan (KTSP) IPA kelas V Sekolah Dasar, ada beberapa kajian materi yang harus dikuasai siswa Sekolah Dasar. Salah satu bidang kajian tersebut adalah dimana konsep Materi Makhluk Hidup Menyesuaikan Diri dengan Lingkungannya ini sangat dekat dengan aktivitas keseharian siswa dalam lingkungannya.

Dalam memahami konsep Makhluk Hidup Menyesuaikan Diri dengan Lingkungannya dibutuhkan kreativitas berfikir siswa memahami konsep tersebut dengan mengkonstruksi pemikirannya sendiri sehingga dapat memahami Materi Makhluk Hidup Menyesuaikan Diri dengan Lingkungannya dengan baik. Olehnya itu seorang guru perlu merancang suatu pembelajaran yang menarik bagi siswa dalam menanamkan konsep Makhluk Hidup Menyesuaikan Diri dengan Lingkungannya dengan menggunakan berbagai metode dan pendekatan mengajar yang sesuai dalam mengembangkan dan meningkatkan hasil belajar siswa.

Prapenelitian yang dilakukan peneliti di SD Negeri 08 Napabalano ditemukan masalah dalam pembelajaran IPA khususnya materi Makhluk Hidup Menyesuaikan Diri dengan Lingkungannya, hal ini sesuai dengan hasil wawancara dan observasi yang diperoleh peneliti di Sekolah Dasar tersebut.

Dari hasil observasi, bahwa pada pembelajaran IPA di SD Negeri 08 Napabalano khususnya Materi Makhluk Hidup Menyesuaikan Diri dengan Lingkungannya, masih banyak terfokus pada pembelajaran konsep/produk dan besifat penghafalan. Sementara Materi Makhluk Hidup Menyesuaikan Diri dengan Lingkungannya dalam pembelajaran menuntut adanya eksperimen dengan menggunakan alat peraga. Disamping itu guru masih kurang memahami penggunaan pendekatan dalam pembelajaran IPA. Jika masalah tersebut tidak dapat teratasi, maka akan berdampak buruk bagi siswa terutama pada mutu dan hasil belajar siswa pada pembelajaran IPA di Sekolah Dasar.

Fakta lain yang menggambarkan bahwa pembelajaran IPA di Sekolah Dasar masih rendah, ditemukan peneliti ketika melakukan PPL 2 di SD Negeri 08 Napabalano. Penyajian materi dalam Pembelajaran IPA masih banyak dilakukan dengan pembelajaran yang terpusat pada guru, yakni metode ceramah.

Berdasarkan data yang diperoleh dua tahun terakhir bahwa nilai rata-rata hasil ulangan harian siswa materi Makhluk Hidup Menyesuaikan Diri dengan Lingkunannya tahun pelajaran 2014/2015 yang mencapai Kriteria Ketuntasan Minimun (KMM) klasikal hanya mencapai $50 \%$, sementara yang belum mencapai (KMM) 50\%. Sedangkan pada tahun 2015/2016 diperoleh data hasil ulangan harian pada materi Makhluk Hidup Menyesuaikan Diri dengan Lingkungannya yang mencapai KKM mengalami peningkatan yakni 55\% dan yang belum tuntas yakni $45 \%$.

Untuk memecahkan masalah tersebut di atas, maka peneliti menawarkan salah satu model Pendekatan Kontekstual sebagai alternatif perbaikan pembelajaran dalam upaya meningkatkan hasil belajar siswa dalam pembelajaran Materi Makhluk Hidup Menyesuaikan Diri dengan Lingkungannya pada siswa kelas V SD Negeri 08 Napabalano.

Menurut Laksmi Prihantoro, 1986, (dalam Trianto, 2008;62) mengatakan bahwa IPA pada hakekatnya merupakan suatu produk, proses, dan aplikasi. Sebagai produk, IPA merupakan sekumpulan pengetahuan dan sekumpulan konsep serta bagan konsep. Sebagai suatu proses, IPA merupakan proses yang digunakan untuk mempelajari obyek studi, menemukan dan mengembangkan produk-produk IPA. Dan sebagai aplikasi, teori-teori IPA akan melahirkan teknologi yang dapat memberikan kemudahan bagi kehidupan. Oleh karena itu, pemilihan materi dan pedekatan pembelajarannya dibutuhkan wahana yang dapat memfasilitasi tumbuhnya kesadaran tersebut. 
Pada mata pelajaran IPA khususnya Materi Makhluk Hidup Menyesuaikan Diri dengan Lingkungannya dengan Pendekatan Kontekstual sangat penting untuk diterapkan dalam rangka meningkatkan hasil belajar siswa. Hal ini didasarkan pada asumsi bahwa IPA adalah suatu pelajaran yang harus diajarkan sebagai suatu cara berfikir sehingga pelajaran IPA dapat membangun kognitif dan merupakan tangga intelektual yang dinaiki dalam meraih tingkat pengetahuan yang lebih tinggi.

Pendekatan Kontekstual memungkinkan siswa berfikir kreatif dalam menghubungkan antara hal-hal yang berbeda yang telah ada, kemudian membandingkan dengan fenomena-fenomena yang ada di lingkungannya sehingga memunculkan ide atau pandangan yang baru. Sejalan dengan itu Elaine, 2006, (dalam Kunandar, 2007) mengemukakan "Pendekatan Kontekstual melatih anak berfikir kreatif menghubungkan suatu yang tampak tidak berhubungan sehingga menemukan pola baru dalam berfikir". Menurut Nurhadi (Sugiartini, 2015) CTL (Contextual Teaching and Learning) adalah konsep belajar yang mendorong guru untuk menghubungkan antara materi yang diajarkan dan situasi dunia nyata siswa.

Melalui Pendekatan Kontekstual juga dapat membantu guru mengaitkan antara Materi Makhluk Hidup Menyesuaikan Diri dengan Lingkungannya dengan situasi dunia nyata siswa, dan mendorong siswa membuat hubungan antara pengetahuan yang dimilikinya dengan penerapannya dalam kehidupan mereka sehari-hari, baik sebagai anggota keluarga dan masyarakat, dengan konsep itu hasil pembelajaran diharapkan lebih menarik bagi siswa, dan dapat meningkatkan hasil belajar siswa dengan baik.

Penelitian yang dilakukan Suparapto (2015) ada perbedaan hasil belajar kognitif yang signifikan pada pelajaran sepeda motor antara kelompok siswa yang diberi perlakuan dengan model pembelajaran kontekstual dan kelompok siswa yang diberi perlakuan dengan model pembelajaran langsung. Serta tidak ada interaksi antara model pembelajaran dan motivasi berprestasi terhadap hasil belajar kognitif.

Berdasarkan dasar-dasar pemikiran dan kenyataan di lapangan , peneliti terdorong untuk melakukan Penelitian Tindakan Kelas (PTK) yang bejudul: "Meningkatkan Hasil Belajar Siswa pada Materi Makhluk Hidup Menyesuaikan Diri dengan Lingkungannya melalui Pendekatan Kontekstual di Kelas V SD Negeri 08 Napabalano"

Masalah dalam penelitian ini adalah: Apakah hasil belajar siswa Materi Makhluk Hidup Menyesuaikan Diri dengan Lingkungannya dapat ditingkatkan melalui pendekatan Kontekstual di Kelas V SD Negeri 08 Napabalano Tujuan penelitian ini adalah Meningkatkan hasil belajar siswa melalui Materi Makhluk Hidup Menyesuaikan Diri dengan Lingkungannya menggunakan Pendekatan Kontekstual di Kelas V SD Negeri 08 Napabalano. Penelitian ini diharapkan dapat memberikan manfaat bagi guru, siswa, sekolah dan penelitian lainnya.

\section{Metode}

Jenis penelitian adalah penelitian tindakan kelas (PTK. Penelitian ini dilaksanakan pada semester ganjil tahun pelajaran 2016/2017 di SD Negeri 08 Napabalano Kab. Muna dengan subyek dalam penelitian ini adalah siswa Kelas VI SD Negeri 08 Napabalano semester I Tahun Pelajaran 2016/2017 dengan jumlah siswa 23 orang. Penelitian tindakan kelas ini dilaksanakan dalam dua siklus yang terdiri dari empat tahapan yaitu perencanaan, pelaksanaan tindakan, observasi dan evaluasi serta refleksi Jenis data dalam penelitian ini adalah data kualitatif dan kuantitatif. Data kualitatif berupa kegiatan proses pembelajaran aktivitas belajar siswa dan aktivitas guru. Data kuantitatif berupa nilai hasil belajar siswa. Sumber data dalam penelitian ini adalah guru dan siswa Kelas V SD Negeri 08 Napabalano. 
Data kualitatif akan dianalisis secara deskriptif kualitatif berdasarkan observasi, sedangkan data kuantitatif dianalisis secara kuantitatif menggunakan rumus:

1. Menentukan Nilai Siswa

$$
\overline{\mathrm{X}}=\frac{\sum x}{n} \quad \text { (Suparno, 2008: 80) }
$$

2. Ketuntasan Klasikal

$$
\% \text { Tuntas }=\frac{\sum f_{i}}{n} \times 100 \% \quad \text { (Suparno, 2008: 82) }
$$

Indikator keberhasilan dalam penelitian ini adalah Proses pembelajaran dikatakan terlaksana dengan baik apabila presentase proses pembelajaran mencapai $80 \%$. Siswa dikatakan menguasai materi yang diajarkan apabila minimal $80 \%$ siswa telah memperoleh nilai minimal 70 (KKM yang ditetapkan sekolah).

\section{Hasil}

\section{Aktivitas Guru}

Berdasarkan lembar observasi aktivitas guru selama proses pembelajaran siklus I berlangsung diperoleh persentase aktivitas guru pada pertemuan I sebesar 60,00\%dan pertemuan II sebesar $66,67 \%$.

Berdasarkan lembar observasi aktivitas guru selama proses pembelajaran siklus II berlangsung diperoleh persentase aktivitas guru pada pertemuan I sebesar 93,33\%dan pertemuan II 93,33\%, secara umum sudah dapat dikatakan semua komponen dalam rencana perbaikan sudah telaksana mencapai standar yang telah ditetapkan yaitu $80 \%$.

2. Aktivitas Siswa

Berdasarkan lembar observasi aktivitas siswa selama proses pelajaran berlangsung siklus I diperoleh persentase aktivitas siswa pada pertemuan I adalah sebesar $61,53 \%$ dan pertemuan II adalah sebesar 69,23\%.

Berdasarkan hasil observasi aktivitabelajar siswa pada siklus II pada pertemuan pertama jumlah skor aktivitas belajar siswa yang tercapai adalah 12 dari 13 jumlah skor maksimal dengan persentase $92,30 \%$ dan pertemuan kedua jumlah skor aktivitas siswa yang tercapai adalah 12 dari 13 jumlah skor maksimal dengan persentase 92,30\%, ketercapaian skenario pelaksanaan perbaikan pembelajaran pada siklus II pertemuan pertama dan kedua telah mencapai standar keterlaksanaan yang telah ditentukan yaitu $80 \%$.

3. Hasil Belajar Siswa

Setelah pelaksanaan tindakan siklus I selama 2 kali pertemuan, diadakan evaluasi tes. Hasil tes siklus I menunjukkan bahwa dari 15 orang siswa hanya 9 orang $(60,00 \%)$ yang memperoleh nilai 70, sedangkan 6 orang lainnya (40,00\%) masih di bawah nilai ketuntasan dengan nilai rata-rata klasikal sebesar 70,66. Karena tingkat ketuntasan belajar siswa belum mencapai indikator keberhasilan maka penelitian dilanjutkan pada siklus II. Dari hasil yang diperoleh pada pelaksanaan tindakan siklus I ke siklus II terjadi peningkatan sebesar $40 \%$ yaitu dari 60\% menjadi 100\% dengan secara rata-rata naik menjadi 16,34. Dengan demikian karena indikator kinerja yang ditetapkan telah tercapai maka pelaksanaan tindakan kelas dihentikan sampai pada siklus II.

\section{Pembahasan}

Penelitian ini dilaksanakan dalam dua siklus dan tiap siklus memiliki dua pertemuan. Pembelajaran yang berlangsung menggunakan pendekatan kontekstual materi Makhluk Hidup (Hewan dan Tumbuhan) Menyesuaikan Diri dengan Lingkungannya.

Peningkatan hasil belajar sangat dipengaruhi oleh aktivitas siswa dan cara mengajar guru dengan menerapkan Pendekatan Kontekstual, hal ini dapat ditunjukkan berdasarkan hasil 
observasi pelaksanaan tindakan untuk siklus I pada pelaksanaan proses pembelajaran pertemuan pertama jumlah skor hasil aktivitas mengajar guru adalah 9 dari 15 skor maksimal dengan persentase $60 \%$ dan pertemuan kedua jumlah skor aktivitas mengajar guru adalah 10 dari 15 skor maksimal dengan persentase $66,66 \%$, ketercapaian skenario pelaksanaan perbaikan pembelajaran pada siklus I pertemuan pertama dan kedua belum mencapai standar keterlaksanaan yang telah ditetapkan yaitu $80 \%$.

Pada siklus II pertemuan pertama jumlah skor hasil aktivitas mengajar guru adalah 14 dari 15 jumlah skor dengan persentase ketuntasan 93,33\% dan pertemuan kedua jumlah skor aktivitas mengajar guru adalah 14 dari 15 jumlah skor dengan persentase 93,33\%, ketercapaian skenario pelaksanaan perbaikan pada siklus II pertemuan pertama dan kedua jumlah persentasenya sama yaitu 93,33\%, artinya secara umum semua komponen dalam rencana perbaikan pembelajaran sudah terlaksana dan mencapai stndar yang ditetapkan yaitu $80 \%$.

Aktivitas belajar siswa dengan model pembelajaran Kontekstual di setiap siklus menunjukkan peningkatan, hal ini dapat dilihat dari tahap-tahap aktivitas belajar siswa pada siklus I pada pertemuan pertama terlaksana hanya 61,50\% dan pertemuan kedua $69,20 \%$. Kemudian siklus II pertemuan pertama dan kedua menunjukkan peningkatan yang sama yaitu $92,30 \%$.

\section{Simpulan}

Berdasarkan hasil penelitian dan pembahasan, disimpulkan bahwa pendekatan kontekstual dapat meningkatkan hasil belajar siswa pada materi pokok Makhluk Hidup Mempertahankan Diri dengan Lingkungannya di kelas V SD Negeri 08 Napabalano. Hal ini dapat dilihat dari aktivitas guru pada siklus I pertemuan 1 sebesar $60,00 \%$ dan pertemuan II sebesar $66,67 \%$. Sedangkan persentase aktivitas siswa pada pertemuan ` 1 sebesar $61,53 \%$ dan pertemuan 2 sebesar $69,23 \%$. Observasi aktivitas guru selama proses pembelajaran siklus II pada pertemuan 1 dan 2 yang mencapai persentase sebesar 93,33\% dan 93,33\%.Sedangkan aktivitas siswa pada pertemuan 1 dan 2 sebesar 92,30\% dan 92,30\%. Nilai yang diperoleh siswa setelah tindakan pembelajaran siklus I dan siklus II dianalisis untuk mengetahui ketuntasan belajar siswa. Pada siklus I, 9 orang siswa $(60,00 \%)$ telah mencapai ketuntasan belajar, 6 orang siswa $(40,00)$ belum mencapai ketuntasan belajar. Sedangkan pada siklus II, 15 orang siswa (100\%) telah mencapai ketuntasan belajar. Hal tersebut menunjukkan bahwa ketuntasan belajar siswa telah mencapai indikator yang telah ditetapkan.

\section{Referensi}

Gugiartini, G.A., dkk. (2015). Pengaruh Penggunaan Metode Pembelajaran Kontekstual Berbatuan Media Gambar Terhadap Motivasi dan Hasil Belajar IPA Pada Siswa Kelas VI SLB Negeri Gianyar. https://www.neliti.com/id/publications/207477/pengaruh-penggunaan-metodepembelajaran-kontekstual-berbantuan-media-gambar-terh.

Kunandar (2007). Guru Profesional: Implementasi Kurikulum Tingkat Satuan Pendidikan (KTSP) dan Sukses Dalam Sertifikasi Guru. Jakarta: Rajagrafindo.

Suparno. P. (2008). Riset Tindakan Untuk Pendidikan. Jakarta: Grasindo. 
Suprapto, E. (2015). Pengaruh Model Pembelajaran Kontekstual, Pembelajaran Langsung dan Motivasi Berprestasi terhadap Hassil Belajar Kognitif. INVOTEC Vol. XI Nomor 1. $\quad$ https://media.neliti.com/media/publications/66130-ID-pengaruh-modelpembelajaran-kontekstual.pdf.

Trianto. (2008). Mendesain Pembelajaran Kontekstual (Contextual Teaching \& Learning) di Kelas. Jakarta: Cerdas Pustaka Publisher 